\begin{tabular}{c} 
Volume and Issues Obtainable at Center for Sustainability Research and Consultancy \\
Journal of Business and Social Review in Emerging Economies \\
ISSN: 2519-089X (E): 2519-0326 \\
Volume 6: No. 3, 2020 \\
JSR \\
Journal homepage: www.publishing.globalcsrc.org/jbsee \\
\hline
\end{tabular}

\title{
Relationship between Teachers' Professional Commitment and Formative Assessment Practices as a Part of Curriculum Implementation at Secondary Level in Punjab
}

\author{
${ }^{1}$ Muhammad Naseer, ${ }^{2}$ Rafaqat Ali Akbar, \\ ${ }^{1} \mathrm{PhD}$ Scholar, Institute of Education and research, University of the Punjab, Lahore, Pakistan, naseerch117@ gmail.com \\ ${ }^{2}$ Professor \& Director at Institute of Education \& Research, University of the Punjab, Lahore, Pakistan, \\ director.ier@pu.edu.pk
}

\begin{tabular}{l}
\hline ARTICLE DETAILS \\
\hline History \\
Revised format: August 2020 \\
Available Online: September \\
2020
\end{tabular}

Keywords

Professional commitment, formative assessment, English curriculum, implementation

\section{JEL Classification}

$M 1, M 2$

\begin{abstract}
National Curriculum for English in Pakistan, reveals its intentions for acquiring language related international requirements concerning with career choices and furthering education. Formative assessment is at the center of students' learning and is devised in the curriculum document providing basis for its implementation. Curriculum implementation is pivotal to classroom practices of teachers. Curriculum guides teachers to implement formative assessment. Professional commitment contributes enriching teacher' classroom practices. Focus of the study was to examine formative assessment practices of teachers, as a part of curriculum implementation, in accordance with curriculum document and its relationship with professional commitment of secondary school English teachers. Study secures its significance for teachers, curriculum developers, and governmental agencies. Quantitative survey was the method adopted for the study and explanatory correlational design was used. Teachers, concerned with teaching of English at secondary level, from entire secondary schools working under the supervision of the Punjab province were the study population. Sampling procedure employed multistage stratified random sampling technique and 576 teachers were selected as study sample. Two questionnaires were developed that included questionnaire regarding implementation of formative assessment (QIFA) and teachers' professional commitment scale (TPCS). Survey was conducted as a data collection strategy. In statistics, Mean and Spearman correlation were employed. Results revealed that professional commitment of teachers and their formative assessment practices were moderate. Results regarding relationship between the variables; professional commitment of teachers and their formative assessment practices were significant correlated. The study recommended school based teacher trainings to sensitize and enhance teachers' awareness and practices towards formative assessment practices as a part of implementation process. Governmental agencies are needed to focus the situation of professional commitment of teachers and implementation of formative assessment as a part of implementation.
\end{abstract}

(C) 2020 Center for Sustainability Research and Consultancy Pakistan under a Creative Commons Attribution-NonCommercial-ShareAlike 4.0 


\title{
OPEN ACCESS
}

\begin{abstract}
Corresponding author's email address: naseerch117@gmail.com
Recommended citation: Muahmmad, M., Rafaqat, A., A. (2020). Relationship between Teachers' Professional Commitment and Formative Assessment Practices as a Part of Curriculum Implementation at Secondary Level in Punjab. Journal of Business and Social Review in Emerging Economies, 6(3), 1014-1024
\end{abstract}

\section{Introduction}

Curriculum implementation is a process to transform the curriculum idea into enactment. It has become a major educational concern of all education systems (Tumposky \& Adam, 2008). Many of the developed curricula are not implemented because of poor planning for incorporating implementation plan into school based educational program (Ornstein \& Hunkins, 2014). Curriculum developers, school administrators, policy makers, and teachers do not care for the implementation phase (Rogan \& Grayson, 2003; Wiles \& Bondi, 2007). Formative assessment focuses to check student learning outcomes and teachers' capabilities at the same time and elaborates changes in the performance of the learners. It provides value judgments regarding changes that are desired (Linn \& Gronlund, 2000). Students' learning outcomes have an association with classroom practices of teachers (Wahab \& Mustapha, 2015). Formative assessment is one of the components of ESL curriculum that is dealt through teachers' classroom practices (Government of Pakistan, 2006). Teachers' professional commitment effects their classroom practices significantly (Hausman \& Goldring, 2001). Classroom practices are denoted as implementing strategies of various types (Leithwood \& Jantzi, 2008; Seashore Louis, Dretzke, \& Wahlstrom, 2010). Teaching, as a purpose of formative assessment, is the ultimate focus of committed teachers (Sawhney, 2015) and implementation process also demands teachers' professional commitment (Ornstein \& Hunkins, 2014). Sawhney (2015) recommends future researches to explore the factors that influence professional commitment of teachers in carrying out curriculum implementation. To conduct new researches, Talla (2012) favors the area curriculum implementation.

English is international language (Meera \& Jumana, 2015) and, in Pakistan, it has the status of second language (Aronoff \& Rees-Miller, 2007). It is one of the compulsory subjects taught since initial grade to the level of graduation in the province of Punjab. Curriculum document of English claims preparing the learners with language competences (Government of Pakistan, 2006). Curriculum document devises formative assessment procedures for the teachers to practice in English classrooms (Government of Pakistan, 2006; Ornstein \& Hunkins, 2014). Teachers, as key roles in curriculum implementation, are expected to acquire curriculum aspirations through their professionally committed practices (Ornstein \& Hunkins, 2014). Secondary level of education is helpful in integrating earlier levels of language. At this level, learners acquire language skills that are needed for their societal and academic needs (Government of Pakistan, 2006). A commonly observed problem with the students at secondary level is that they are incapable of communicating effectively in English by using the skills related to English language (Dar and Khan, 2015). They demonstrate huge dropout and low percentages of success in the exams due to the English language learning difficulties they face (Awan \& Shafi, 2016). The researcher, during 14 years of his experiences as head teacher and English teacher, has also been observing the same situation. Currently, as a research scholar, I have gone through the document of English curriculum and revealed that it is not implemented truly. English teachers employ conventional classroom practices with limited content knowledge of English (Parveen \& Bhatti, 2009). The study examined the current situation of professional commitment of teachers and their formative assessment practices at secondary level. It also analyzed the relationship between both of the variables.

The study is significant to gather the attention of curriculum experts to match the guidelines given in the curriculum with teachers' capabilities relevant to formative assessment procedures. It is significant for teacher training bodies and governmental agencies to look deep into the present situation of professional commitment of teachers and their role towards curriculum implementation. It is significant for teachers to sense them the need to go through the curriculum document to understand their role as curriculum implementer. Moreover, it is significant to gather their attention towards the level of their commitment as a teacher. The study is also significant for its contribution towards knowledge by grasping a novel context of the research and paving ways for more research the curriculum area, 
especially in Pakistan. In delimitation, curriculum of English and public secondary schools were included as all of these schools in Punjab follow the National Curriculum for English.

\subsection{Objectives}

Objectives for the research were formulated to;

- Examine formative assessment practices of secondary school English teachers as a part of curriculum implementation

- Find out professional commitment level among the teachers concerned to teach the subject of English at secondary level

- Analyze relationship between professional commitment and formative assessment practices of English teachers at secondary level

\section{Review of Literature}

According to Baker \& Westrup (2000), students who possess better skills of English language are more capable to contribute their country in its advancement. Students get formal English learning opportunities through an organized curriculum (Gleeson \& Davison, 2016). Theory of social cognition describes cognition as process to encode and perform behaviors of different kinds (Bandura, 1986). Language grooms as a result of interactions done within the society (Zhou \& Brown, 2017) as stimulus-response theory (Skinner, 1957) proves that acquisition of a language is a process that directly relates to behavior. In ESL classrooms, teachers act as facilitators (Government of Pakistan, 2006) to make their learners active towards the process of learning (Moges, 2019) and use formative assessment as a means of students' learning. National Curriculum for English is a framework prepared as a reference document that provides guidance and insight to the teachers as stakeholders (Government of Pakistan, 2006).

Lo (2005) defines curriculum implementation as a process that brings curriculum into enactment. Curriculum implementation gathers role of teacher as central (Hardman \& Rahman, 2014; Ornstein \& Hunkins, 2014; Remillard, 2005). Teachers' ways of considering and using materials contribute influencing students' learning significantly (Dane \& Schneider, 1998; O’Donnell, 2008). According to Thien, Razak, \& Ramayah (2014), professional commitment of teachers stands among the major concerns of education. Vandenberg \& Scarpello (1994) depict professional commitment as a person's acceptance for the profession he is associated with on the basis of his beliefs. Teachers with professional commitment, demonstrate effective practices related to teaching (Hausman \& Goldring, 2001; Sawhney, 2015; Shamina, 2014). Various indicators such as involvement in the school, efforts to put for achieving its goals (Ibrahim, Ghavifekr, Ling, Siraj, \& Azeez, 2014), and participation in school decision reveal the level of professional commitment of teachers (Yukl, 2010). In their studies, Dannetta (2002) and Nir (2002) present three kinds of professional commitment related to teachers that include commitment to the teaching profession, commitment to their school and students.

According to Linn and Gronlund (2000), students' performance is the main focus of formative assessment. It helps understanding the degree of students' progress towards achieving their learning goals (Linn \& Miller, 2005). Classroom instruction is mingled with formative assessment procedures (Tawalbeh \& Ismail, 2014; Wiggins \& McTighe, 2007). Quiz competitions, questioning techniques, asking for self-reflection, and providing feedback are the kinds of formative assessment (Wiliam \& Thompson, 2008). National curriculum for English, in its assessment section, presents formative assessment procedures that includes constructing class tests, feedback practices of teachers, conducting activities of academic nature, and focusing students' affective traits to assess (Government of Pakistan, 2006). In ESL classrooms, objective type questions help assessing vocabulary, spellings, punctuation, text, and grammar that include true-false statements, filling the blanks, matching of columns (Linn \& Gronlund, 2000), and multiple choice items (McCoubrie, 2004). Open-ended questions include essay type questions and short answer as a part of subjective type questions to assess various language skills (Porst, 2011). Besides second language learning, cocurricular activities contribute in holistic development of the students (Eccles, et al., 2003; Foster, 2007). According to Dongre, Deshmukh, \& Garg (2010), quiz competitions, as a part of formative assessment (Webb, Simposon, Denson, \& Duthie, 2012), enhance motivation and activate learning in learners (Dongre, Deshmukh, \& Garg, 2010). 
Writing demands structural accuracy, appropriation, and strategic use of language based on communicative potential that is needed in second language learning (Dar \& Khan, 2015; Hyland, 2003; Mahboob, 2014). Rewriting also has a significant contribution in improving learning. Teachers asks students for corrections for the purpose to improve their learning (Ur, 1996). Effective speaking and verbal communication (Hall, 2011; Williams, McGee, \& Worth, 2001), self-confidence (Littlefield, 2001), and critical thinking is improved through debates (Freeley \& Steinberg, 2005). Feedback is at the core of students' assessment. It involves assessment of students' work, their self-reflection, class discussions, and peer corrections (Klimova, 2015). According to Baharudin, Chi Yee, Sin Jing, and Zulkefly (2010) and Pomerantz, Moorman, and Litwack (2007), involvement of the parents in school is an indicator that contributes towards students' success (Epstein et al., 2009; Pattnaik \& Sriram, 2010; Wyche, 2010). As a part of affective assessment students' appraisal, regarding their various qualities, is used to motivate them (Hall, 2011). Students' behaviors are also considered as predictors of their outcomes and incorporated with language teaching (Chetty et al., 2011; Government of Pakistan, 2006).

\section{Curriculum Implementation Model}

Concerns-based Adoption Model (CBAM) focuses teachers' concerns about curriculum implementation. Hall and Hord $(2001,1987)$ describe CBAM with its three aspects such as stages of concerns, levels of use, and innovation configurations. It helps teachers in successful implementation of a curriculum (Marsh \& Willis, 2007). Levels of use describes teachers' dimensions related to their behaviours, what actually they practice in the classroom as a part of their experiences of curriculum implementation (Hall \& Hord, 1987). They go through the transition phase of their teaching when they switch to carve teaching in new ways (Horsley, \& Loucks-Horsley, 1998). There are eight steps in the aspect of levels of use that include starting from non-use and moves in sequence of orientation, preparation, mechanical use, routine, refinement, integration, and renewal. A teacher moves through the process of change while implementing a curriculum. All of these levels show how teachers adapt the process of curriculum implementation starting from low level to the highest level. Current study was based mainly on the aspects of levels of use by including maximum contents given the curriculum document.

\section{Theoretical Framework of the Study}

Rogan and Aldous (2005), used this framework in their study. Capacity of the school and teachers to support innovation, outside support profile, and profile of implementation are the constructs studied as components of this framework. Profile of implementation involves assessment as one of its aspects. It helps understanding, analyzing, and expressing the ideals of a curriculum and its extent to which it is being taken into practice. According to Fullan (1991), appearance of the next steps is one of the key features related to practical side of curriculum implementation process. The profile of implementation helps curriculum planners conceptualizing the levels of implementation of a new curriculum that helps them determining their present strengths. They can look into the capacity of the school over a number of years to adopt and phasing a new curriculum. They become part of the planning for contextualizing the school culture in appropriation with implementation of change. Developmental planning contributes providing new ways for the sensible spread of the changes in the forthcoming years. It also contributes improving control of the school over the desired content that leads the change (Hargreaves \& Hopkins, 1991). 


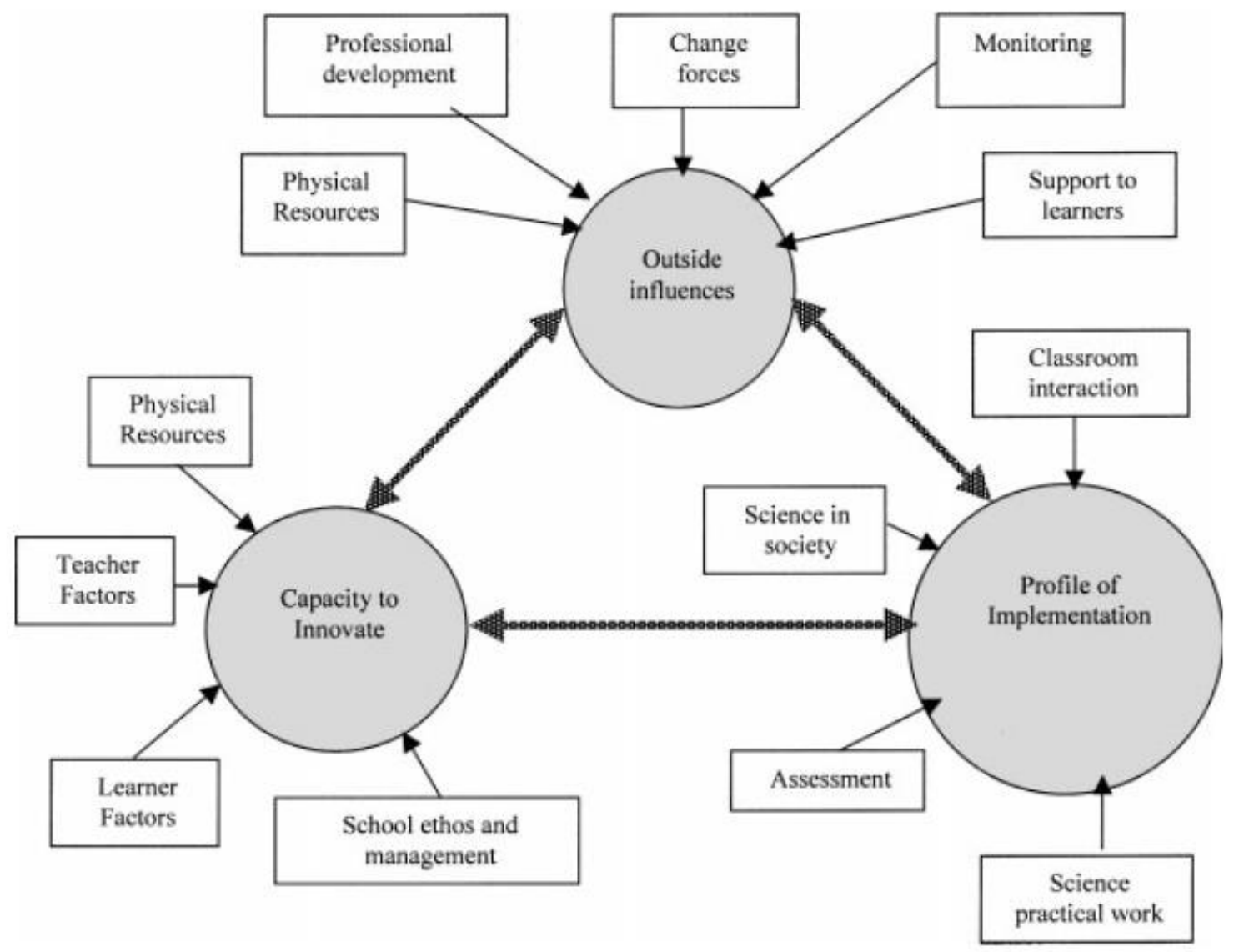

\section{Methodology}

Theoretical framework of the study (adopted from Rogan \& Aldous, 2005).

The study was quantitative and survey approach was used. Correlational explanatory research design (Creswell, 2012) was employed. Male and female entire public secondary school English teachers, Punjab province, was the study population. While selecting sample for the study, equal representation of respondents were kept in view on the bases of their school locale and gender through multistage random sampling technique. From all the nine divisions in Punjab, taking two districts from each division, eighteen districts were selected. Sixteen schools were selected from each district on equal bases of their gender and locale. Consequently, selecting two teachers from each school, 576 teachers were taken as study sample. Description of the study sample is given in the following table:

Table 1: Description of the sample

\begin{tabular}{llllll}
\hline \multirow{2}{*}{ Category of teachers } & Rural locale & \multicolumn{3}{l}{ Urban locale } & Total \\
\cline { 2 - 5 } & Females & Males & Females & Males & 576 \\
\hline Respondents & 144 & 144 & 144 & 144 & 576 \\
\hline
\end{tabular}

\subsection{Instrumentation}

Questionnaire regarding implementation of formative assessment (QIFA) and teachers' professional commitment scale (TPCS) were personally developed presenting five point Likert Scale Measuring. Following is the detail of both of the questionnaires:

\subsection{Teachers' Professional Commitment Scale (TPCS)}

This scale was developed for data collection from the respondents about their level of commitment with their profession. In the light of existing literature, the scale presents three aspects of professional commitment including commitment to teaching profession, students, and school. It consisted upon 24 statements. Factor wise distribution of the items is provided in the table below: 
Table 2: Detail of factor wise items in TPCS

\begin{tabular}{lll}
\hline Sr. No. & Factors & Serial Number of Items \\
\hline 1 & Commitment to profession & 1 to 8 \\
2 & Commitment to students & 9 to 18 \\
3 & commitment to school & 19 to 24 \\
\hline
\end{tabular}

\section{Questionnaire Regarding Implementation of Formative Assessment (QIFA)}

Questionnaire regarding implementation of formative assessment was developed for the respondents to collect data about their formative assessment practices. It was developed in accordance with existing literature and suggestions provided in the curriculum document. It consisted upon 20 statements. Following table presents factor wise distribution of questionnaire statements:

Table 3: Detail of factor wise items in QIFA

\begin{tabular}{lll}
\hline Sr. No. & Factors & Serial Number of Items \\
\hline 1 & Test construction & $1,2,3,4,5,6$ \\
2 & Co-curricular activities & $7,8,9$ \\
3 & Feedback & $10,11,12,13,14,15$ \\
4 & Affective traits & $16,17,18,19,20$ \\
\hline
\end{tabular}

\subsection{Validity and reliability of the instruments}

From three universities, recognized by Higher Education Commission (HEC), five experts in education were consulted for ensuring internal validity of the questionnaires. Both of the questionnaires were improved in the light of their opinions. Small sample pilot testing was carried out from the selected subgroups. Questionnaires were improved keeping in view the point-outs extended by the respondents. The data, collected through piloting, were calculated to find Cronbach's Alpha. The Alpha values of TPCS and QIFA were found .890 and .910 respectively. Data were collected in natural settings through surveys (Fraenkel, Wallen, \& Hayun, 2012; Gay, Mills, \& Airasian, 2012; Scott \& Morrison, 2006).

Alpha values of the questionnaires is presented in the table given in the following:

Table 4: Alpha values of TPCS and QIFA

\begin{tabular}{llll}
\hline Sr. No. & Scales & Items & N \\
\hline 1 & Teachers' professional commitment scale & 24 & 32 \\
2 & Questionnaire regarding implementation of formative assessment & .890 & 20 \\
\hline
\end{tabular}

\section{Data Analysis}

Mean scores were calculated for examining teachers' formative assessment practices and their professional commitment level. Spearman correlation was applied for analyzing relationship between professional commitment of teachers and their practices towards formative assessment. Statistical results, from data, were described analytically that led to conclusions of the study.

\section{Results}

\subsection{Formative Assessment}

\section{Table 5: Formative Assessment Practices of Teachers}

\begin{tabular}{|c|c|c|c|c|c|c|c|c|}
\hline $\begin{array}{l}\text { Sr. } \\
\text { No. }\end{array}$ & Aspects & $\begin{array}{l}\mathrm{A} \\
\%\end{array}$ & $\begin{array}{l}\mathrm{O} \\
\%\end{array}$ & $\begin{array}{l}\mathrm{S} \\
\%\end{array}$ & $\begin{array}{l}\mathrm{R} \\
\%\end{array}$ & $\begin{array}{l}\mathrm{N} \\
\%\end{array}$ & M & SD \\
\hline 1 & Constructing class tests & 27.12 & 27.38 & 25.05 & 15.02 & 5.37 & 3.56 & 1.19 \\
\hline 2 & Co-curricular activities & 15.40 & 28.70 & 27.20 & 18.53 & 10.16 & 3.21 & 1.21 \\
\hline 3 & Feedback & 28.70 & 27.03 & 23.85 & 13.88 & 6.52 & 3.58 & 1.22 \\
\hline 4 & Affective traits & 30.50 & 23.14 & 23.34 & 15.48 & 7.54 & 3.53 & $\begin{array}{l}1.27 \\
1.22\end{array}$ \\
\hline
\end{tabular}

$\mathrm{N}=576$, Level ranges defined as Low $=(1.00$ to 2.33$)$, Moderate $=(2.34$ to 3.66$), \&$ High $=(3.67$ to 5.00$)$

In table 5 results about formative assessment practices of teachers are presented. Overall mean score of teachers' formative assessment factors were found to be $(M=3.47, S D=1.22)$. Sub-factors show results based on mean values, as perceived by secondary school English teachers, were found such as constructing class tests $(M=3.56, S D=1.19)$, 
conducting activities of co-curricular nature $(M=3.21, S D=1.21)$, providing feedback $(M=3.58, S D=1.22)$, and assessing affective traits of the students $(M=3.53, S D=1.27)$. Results reveal that teachers are moderate in formative assessment practices they do in the classrooms. None of the sub-factors related to formative assessment is at high level. It means formative assessment practices of the teachers towards implementing curriculum of English at secondary level are found at moderate level. Among the sub-factors, conduction of co-curricular activities is found at the lowest to all.

\section{Professional Commitment of Teachers}

Table 6: Professional commitment of teachers

\begin{tabular}{|c|c|c|c|c|c|c|c|c|}
\hline $\begin{array}{l}\text { Sr. } \\
\text { No. }\end{array}$ & Factors & $\begin{array}{l}\text { SA } \\
\%\end{array}$ & $\begin{array}{l}\mathrm{A} \\
\% \\
\end{array}$ & $\begin{array}{l}\mathrm{U} \\
\%\end{array}$ & $\begin{array}{l}\mathrm{D} \\
\%\end{array}$ & $\begin{array}{l}\text { SD } \\
\% \\
\end{array}$ & M & SD \\
\hline 1 & Commitment to profession & 18.43 & 36.84 & 10.63 & 25.00 & 9.11 & 3.31 & 1.17 \\
\hline 2 & Commitment to students & 28.49 & 50.19 & 7.60 & 11.03 & 2.68 & 3.91 & 0.99 \\
\hline 3 & $\begin{array}{l}\text { Commitment to school } \\
\text { Overall }\end{array}$ & 24.07 & 44.02 & 9.72 & 16.78 & 5.38 & $\begin{array}{l}3.65 \\
3.62\end{array}$ & $\begin{array}{l}1.10 \\
1.09\end{array}$ \\
\hline
\end{tabular}

Table 6 shows results about the level of professional commitment of teachers. Mean score $(M=3.62, S D=1.09)$ of the variable reveal that teachers possess professional commitment moderately. Teachers exhibited high level of their commitment towards their students as the mean score was found to be $(M=3.91, S D=0.99)$. Two of the sub-factors; commitment to teaching profession $(M=3.31, S D=1.17)$ and towards school $(M=3.65, S D=1.10)$ showed moderate level of teachers' commitment. It means teachers are not highly committed to their profession as a teacher.

\section{Relationship between Professional Commitment of Teachers and Formative Assessment}

Table 7: Relationship between professional commitment of teachers and formative assessment practices

\begin{tabular}{lllll}
\hline Factors & Mean & $N$ & $\begin{array}{l}\text { Spearman's rho } \\
\left(r_{s}\right)\end{array}$ & $\begin{array}{l}\text { Sig (2-tailed) } \\
(p)\end{array}$ \\
\hline Professional Commitment of Teachers & 3.64 & 576 & $.109^{* *}$ & .009 \\
Formative Assessment Practices & 3.51 & 576 & .57 & \\
\hline
\end{tabular}

**. Correlation is significant at the 0.01 level (2-tailed).

Table 7 reveals relationship between professional commitment of teachers and their formative assessment practices. Spearman's rho correlation coefficient was used to measure the relationship between the variables. Results $r_{s}=.109, p$ $=.009<0.01$ depict significant relationship between professional commitment of teachers and their formative assessment practices. It adds that there is high positive correlation between both of the variables.

\section{Conclusions}

Following are the study conclusions:

- Teachers do not follow the patterns and guidelines for formative assessment as given in the curriculum document of English as a part of implementation

- Professionally, secondary school English teachers lack in commitment

- Teachers' professional commitment exhibits significant relationship with their formative assessment practices

\section{Recommendations}

Following are the recommendations drawn for the study:

- Three days training workshop at school level may be conducted to make the teachers familiar with the document of English curriculum with the intentions of their role in its implementation of formative assessment procedures

- Social media may be used for teachers' sensitization towards their committed role as a teacher

- School administration and governmental agencies may be conveyed about the current situation of professional commitment of teachers and level of curriculum implementation for effective planning to enhance the both

- Following studies may be recommended in the same area: 
i) A qualitative study may be conducted to examine awareness of teachers regarding curriculum document of English and how do they recognize their role in its implementation

ii) School based training program may be developed through a research that would help improving teachers effectiveness as curriculum implementer

iii) Causes for the moderate level of teachers' professional commitment may be explored by conducting a research in the context of present research

\section{References}

Aronoff, M., \&, Rees-Miller, J. (2007). The handbook of linguistics. Oxford: Blackwell.

Awan, A. G., \& Shafi, M. (2016). Analysis of Teaching Methods of English Language at Government Secondary School Level in D.G. Khan City-Pakistan. Global Journal of Management and Social Sciences, 2(2), 29-46.

Baharudin, R., Chi Yee, H., Sin Jing, L., \& Zulkefly, N. (2010). Educational goals, parenting practices and adolescents' academic achievement. Asian Social Science, 6(12), 144-152.

Baker, J., \& Westrup, H. (2000). The English language teacher's handbook. London: Continuum.

Bandura, A. (1986). Social foundations of thought \& action: A social cognitive theory. Upper Saddle River, NJ: Prentice-Hall.

Chetty, R., Friedman, J. N., Hilger, N., Saez, E., Schanzenbach, D., \& Yagan, D. (2011). How does your kindergarten classroom affect your earnings? Evidence from Project STAR. Quarterly Journal of Economics, 126(4), 15931660.

Creswell, J. W. (2012). Educational research: Planning, conducting, and evaluating quantitative and qualitative research ( $4^{\text {th }}$ ed.). New York: Pearson.

Dane, A. V., \& Schneider, B. H. (1998). Program integrity in primary and early secondary prevention: are implementation effects out of control?. Clinical psychology review, 18(1), 23-45.

Dannetta, V. (2002). What factors influence a teacher's commitment to student learning?. Leadership and Policy in Schools, 1(2), 144-171.

Dar, M. F., \& Khan, I. (2015). Writing anxiety among public and private sectors Pakistani undergraduate university students. Pakistan Journal of Gender Studies, 10(1), 121-136.

Dongre, A. R., Deshmukh, P. R., \& Garg, B. S. (2009). Using the 'transect walk' as a public health teaching and learning tool. Medical education, 43(11), 1093-1094.

Dongre, A. R., Deshmukh, P. R., \& Garg, B. S. (2010). Portfolio based approach for teaching Community Medicine among medical undergraduates and assessment of their learning in a Medical college of rural India. South East Asian Journal of Medical Education, 4(1), 17-24.

Eccles, J. S., Barber, B. L., Stone, M., \& Hunt, J. (2003). Extracurricular activities and adolescent development. Journal of social issues, 59(4), 865-889.

Epstein, M., Atkins, M., Cullinan, D., Kutash, K., \& Weaver, K. (2008). Reducing behavior problems in the elementary school classroom. IES Practice Guide, 20(8), 12-22.

Foster, C. R. (2007). Extra-curricular activities in the high school. Read Books.

Freeley, A. J., \& Steinberg, D. L. (2005). Argumentation and Debate (11 ${ }^{\text {th }}$ ed.). Belmont, CA: Thomson-Wadsworth.

Fullan, M.G. (1991). The new meaning of educational change. New York: Teachers College Press.

Gleeson, M., \& Davison, C. (2016). A conflict between experience and professional learning: Subject teachers' beliefs about teaching English language learners. RELC Journal, 47(1), 43-57.

Government of Pakistan. (2006). National curriculum for English language grades I - XII 2006. Islamabad: Ministry of Education.

Hall, D., (2011). Debate: Innovative teaching to enhance critical thinking and communicative skills in healthcare professionals. The Internet Journal of Allied Sciences and Practice, 9(3), 1-8.

Hall, G. E., \& Hord, S. M. (1987). Change in schools: Facilitating the process. Suny Press.

Hall, G. E., \& Hord, S. M. (2001). Implementing change: Patterns, principles, and potholes. Boston, MA: Allyn and Bacon.

Hall, R. A. (2011). Affective assessment: The missing piece of the educational reform puzzle. Delta Kappa Gamma Bulletin, 77(2), 7-10.

Hardman, J., \& A-Rahman, N. (2014). Teachers and the implementation of a new English curriculum in Malaysia. Language, Culture and Curriculum, 27(3), 260-277. 
Hargreaves, D.H. \& Hopkins, D. (1991). The empowered school. The management and practice of development planning. London: Cassell Educational Limited.

Hausman, C. S., \& Goldring, E. B. (2001). Sustaining teacher commitment: The role of professional communities. Peabody Journal of Education, 76(2), 30-51.

Horsley, D. L., \& Loucks-Horsley, S. (1998). CBAM Brings Order to the Tornado of Change. Journal of staff development, 19(4), 17-20.

Hyland, K. (2003). Second language writing. Ernst Klett Sprachen.

Ibrahim, M. S., Ghavifekr, S., Ling, S., Siraj, S., \& Azeez, M. I. K. (2014). Can transformational leadership influence on teachers' commitment towards organization, teaching profession, and students learning? A quantitative analysis. Asia Pacific Education Review, 15(2), 177-190.

Klimova, B. (2015). The role of feedback in EFL classes. Procedia-Social and Behavioral Sciences, 199, $172-177$. doi: 10.1016/j.sbspro.2015.07.502

Leithwood, K., \& Jantzi, D. (2008). Linking leadership to student learning: The contributions of leader efficacy. Educational administration quarterly, 44(4), 496-528.

Linn, R. L., \& Gronlund, N. E. (2000). Measurement and assessment in teaching (8 ${ }^{\text {th }}$ ed.). NJ: Merrill.

Linn, R., \& Miller, M. D. (2005). Measurement and evaluation in teaching. Upper Saddle River, NJ: Merrill.

Littlefield, R., (2001). High school student perceptions of the efficacy of debate participation. Argumentation and Advocacy, 38(2), 83-97.

Lo, A. W. (2005). Reconciling efficient markets with behavioral finance: the adaptive markets hypothesis. Journal of investment consulting, 7(2), 21-44.

Mahboob, A. (2014). Epilogue: Understanding language variation: Implications for EIL pedagogy. In The pedagogy of English as an international language: Perspectives from scholars, teachers, and students, 1, 257-265. doi: 10.1007/978-3-319-06127-6

Marsh, J. M. C., \& Willis, G. (2007). Curriculum: Alternative approaches, ongoing issues (4 ${ }^{\text {th }}$ ed.). NJ: Pearson.

McCoubrie, P. (2004). Improving the fairness of multiple-choice questions: a literature review. Medical teacher, 26(8), 709-712.

Meera, K. P., \& Jumana, M. K. (2015). Self-Efficacy and Academic Performance in English. Research in Pedagogy, 5(2), 25-30.

Moges, B. (2019). Practices and Challenges of Cooperative Learning in Selected College of Arsi University: As a Motivational Factor on Enhancing Students' Learning. Universal Journal of Psychology, 7(1), 1-17.

Nir, A. E. (2002). School- based management and its effect on teacher commitment. International Journal of Leadership in Education, 5(4), 323-341.

O’Donnell, C. L. (2008). Defining, conceptualizing, and measuring fidelity of implementation and its relationship to outcomes in K-12 curriculum intervention research. Review of Educational Research, 78(1), 33-84.

Ornstein, A. C., \& Hunkins, F. P. (2014). Curriculum foundations, principles, and issues $\left(6^{\text {th }}\right.$ ed.). UK: Pearson.

Parveen, M., \& Bhatti, T. (2009). Quality Assurance in English language teachers Programmes offered through Diatance Mode of Education The Sindh University Journal of Education, 28(28), 1-17.

Pattnaik, J. \& Sriram, R. (2010). Father/male involvement in the care and education of children. Childhood Education, 86(6), 354-359.

Pomerantz, E. M., Moorman, E. A., \& Litwack, S. D. (2007). The how, whom, and why of parents' involvement in children's academic lives: More is not always better. Review of educational research, 77(3), 373-410.

Porst, R. (2011). Fragebogen. Ein Arbeitsbuch. Wiesbaden: VS-Verlag.

Remillard, J. T. (2005). Examining key concepts in research on teachers' use of mathematics curricula. Review of educational research, 75(2), 211-246.

Rogan, J. M., \& Grayson, D. J. (2003). Towards a theory of curriculum implementation with particular reference to science education in developing countries. International Journal of Science Education, 25(10), 1171-1204.

Rogan, J., \& Aldous, C. (2005). Relationships between the constructs of a theory of curriculum implementation. Journal of Research in Science Teaching: The Official Journal of the National Association for Research in Science Teaching, 42(3), 313-336.

Sawhney, N. (2015). Professional commitment among secondary school teachers in relation to location of their school. Global Journal for Research Analysis, 4(8), 238-239.

Seashore Louis, K., Dretzke, B., \& Wahlstrom, K. (2010). How does leadership affect student achievement? Results 
from a national US survey. School effectiveness and school improvement, 21(3), 315-336.

Shamina, H. (2014). Impact of job satisfaction on professional commitment in higher education. Galaxy International Interdisciplinary Research Journal, 2(2), 1-11.

Skinner, B. F. (1957). Verbal behavior. New York: Appleton-Century-Crofts.

Talla, M. (2012). Curriculum development: Perspectives, principles and issues. Delhi: Pearson.

Tawalbeh, T. E. I., \& Ismail, N. M. (2014). Investigation of Teaching Competencies to Enhance Students' EFL Learning at Taif University. International Education Studies, 7(11), 84-96.

Thien, L. M., Razak, N. A., \& Ramayah, T. (2014). Validating teacher commitment scale using a Malaysian sample. Sage open, 4(2), 1-19.

Tumposky, M. R., \& Adam, J. (2008). Staff development and curriculum implementation. The Educational Forum, 51(2), 185-195.

Ur, P. (1996). A Course in Language Teaching, Practice and Theory. Cambridge University Press. Cambridge, UK.

Vandenberg, R. J., \& Scarpello, V. (1994). A longitudinal assessment of the determinant relationship between employee commitments to the occupation and the organization. Journal of Organizational Behavior, 15(6), 535-547.

Wahab, N. A., \& Mustapha, R. (2015). Reflection on pedagogical and curriculum implementation at Orang Asli Schools in Pahang. Social and Behavioral Sciences, 172, 442-448. doi: 10.1016/j.sbspro.2015.01.376

Webb, T. P., Simpson, D., Denson, S., \& Duthie Jr, E. (2012). Gaming used as an informal instructional technique: effects on learner knowledge and satisfaction. Journal of Surgical Education, 69(3), 330-334.

Wiggins, G. P., \& McTighe, J. (2007). Schooling by design: Mission, action, and achievement. ASCD.

Wiles, J. \& Bondi, J. (2007). Curriculum Development: A guide to practice ( $7^{\text {th }}$ ed.). NJ: Pearson.

Wiliam, D. \& Thompson, M. (2008). Integrating Assessment with Learning: What Will It Take to Make It Work? In: Dwyer, CA, (ed.), The Future of Assessment: Shaping Teaching and Learning. (pp. 53-82). Routledge: New York, NY, USA.

Williams, D. E., McGee, B. R., \& Worth, D. S. (2001). University student perceptions of the efficacy of debate participation: An empirical investigation. Argumentation and Advocacy, 37(4), 198-209.

Yukl, G. A. (2010). Leadership in organization ( $7^{\text {th }}$ ed.). Upper Saddle River, NJ: Prentice Hall.

Zhou, M., \& Brown, D. (Eds.). (2017). Educational learning theories. ( $2^{\text {nd }}$ ed.). Retrieved from https://oer.galileo.usg.edu/education-textbooks/1 